\title{
Naming the body of nobody: The topic of truth in Victor Klemperer's diaries
}

\author{
Michael Rinn \\ Université de Bretagne Occidentale \\ Céditec EA 3119, Paris XII, France \\ e-mail: mirarinn@wanadoo.fr
}

\begin{abstract}
Victor Klemperer, German philologist and Professor at the University of Dresden, bears testimony to his survival during the Nazi years in his Diaries (1933-1945). Progressively excluded from all social life because of his Jewish religion, Klemperer is forced to recognize himself as a non-subject by the end of the war, calling himself "Nobody" in reference to Ulysses with Polyphemus, the Cyclops. Our article aims to show the mental — cognitive and corporal - process underlying this recognition. Our study will explore the two-pronged thrust of this process: faced with the inexorable destruction of his self, Klemperer has to acknowledge the limits of his analytical capacities. But this extreme experience will enable him to create somatic knowledge destined to recognize what he calls "thought of extinction". To conclude, we show how this reasoning is based upon action language which consists in naming the body.
\end{abstract}

We shall try to show how the exceptional testimonial value of Victor Klemperer's Diaries (1933-1945) emerges from a formal analysis of his writing. A German citizen declared to be a Jew by the laws of Nuremberg, Victor Klemperer appropriates his writing as a philological investigation of what he calls the LTI (the Lingua Tertii Imperii), the language of the 3rd Reich invading the sphere of public and private life. Our study will center on how Klemperer develops over the years a rhetorical strategy designed to textualize an extreme experience. On the conceptual level, this strategy is based upon the 
new formalization of the rhetorical category of the plausible: the topic of implausible truth.

We propose to develop two hypotheses: on the one hand, Klemperer tries to make his testimony credible by availing himself of the argumentative domain of ethos. In the rhetorical tradition, construction of a self-image (ethos) attempts to make the listeners trust the orator, highlighting his character, the sensible nature of his approach and the virtue from which he draws his inspiration. On the other hand, threatened by the Nazis' policy of annihilation, Klemperer will be forced to redefine the relation to self and others, modalizing a testimonial discourse which articulates the argumentative domain of pathos. If the discourse of ethos tends toward abstraction, giving rise to a philological reflection on the LTI, its counterpart in the domain of pathos proceeds by emotional concretion in order to situate the very place of destruction: the body.

\section{Diaries of a non-subject}

Victor Klemperer, who was born in 1881 in Landsberg and died in 1960 in Dresden, began keeping a journal in his youth, writing a chronicle of his life and times. A philologist, a specialist in Romance languages renowned in the field of French literature, a professor at the universities of Munich, Dresden, Greifswald, Halle and, at the end of his career, at Humboldt University in East Berlin, he became a major witness to the Nazis' criminal policy (Mieder 2000; Jacobs 2000). Victor Klemperer was from a family of rabbis, and he converted to Protestantism at the age of twenty-two in order to make it clear that he fit into German culture. A firm conviction made him reject all incentives to flee the Hitlerian regime in spite of ever more threatening signs. He managed to survive this catastrophe, undergoing many ordeals in the process.

The object of our study is less the exceptional testimonial value of the Diaries which Victor Klemperer kept during the Nazi period

\footnotetext{
Among the 16,000 pages of manuscripts in the Dresden library, the following major works have been published: Curriculum vitae. Erinnerungen 1881-1918 (Klemperer 1989); Leben sammeln, nicht fragen wozu und warum. Tagebücher 1918-1932 (Klemperer 1996) and So sitze ich denn zwischen allen Stühlen. Tagebücher 1945-1959 (Klemperer 1999a).
} 
(Dirschauer 1997) than the shaping of his own language. Sometimes ironic and sarcastic, sometimes friendly and generous, but above all intentionally lucid vis-à-vis a self-image which appears to be irrevocably condemned, this total revelation is inspired both by a sense of duty to bear witness and by the spirit of the man of letters: this textualization of the limit consists in representing that which escapes immediate apprehension and assigning a linguistic place to an evolving thought process, particularly in the realm of modern art. ${ }^{2}$

Klemperer's Diaries thus seek to attribute a verbal form to an everelusive reality, defining a living condition whose entire social foundation is progressively undermined. This loss directly threatens the scriptorial act, not in its very materiality, as shown by the hundreds of notes, but in its capacity to refer to a world of established meaning. By established meaning we mean the semio-noetic background postulated, proven, and validated by the doxa, the meaning that is necessary for the development of a topic centered on the logicodiscursive domain. Klemperer's Diaries bear the signs of his times which, from a cultural point of view, will always be - no matter what - ours, in his attempt to formulate that which finds infinite expression only in the representation of radical negativity - the Shoah - and in his appeal to silence, imposed by destruction itself. ${ }^{3}$

Klemperer also shows that the constant vacillation which marks his status as potential deportee corresponds to an organizing principle characterized by an inexorable logic of destruction. If the testimonial act records the elements necessary for the restoration of an individual present, guarantor of a form of existence, however precarious it may be, Klemperer cannot rid himself of the social, cultural and religious identity which defines him, according to the criteria established by the

2 Some passages in the Diaries are of considerable literary value, as seen in our analysis (Rinn 1999a). See also our article on the Hungarian writer Imre Kertész (Rinn 2005).

3 Imre Kertész (1999: 88), Auschwitz survivor, draws the following conclusion: "But the conditions that made Auschwitz were already there, previously, in everyday life; otherwise, Auschwitz couldn't have existed. And knowledge of those conditions remains, precisely, our unfinished business. [...] How can I explain? There are quite simply, in each person's life, unclear areas. They must be swept under the carpet. If we don't come to terms with them, we end up having to deal with forces that surpass our strength". 
Nazis, as a non-subject destined to be put to death. ${ }^{4}$ Klemperer's journal is proof of the unbearable tension between the will to survive in the present of writing and the anticipation of his ultimate destiny.

\section{Destruction of the self-image}

The first hypothesis that we shall develop in this article, the implementation of writing, must be viewed as a procedure for the building of a self-image (which the rhetorical tradition calls ethos), with the aim of strengthening the credibility of the logico-discursive argumentation. However, Victor Klemperer will be unable to escape the role of non-subject inflicted upon him by the Nazis, in spite of the remarkable intellectual effort he makes in order to develop awareness of his situation. What is even worse is that his writing will become the theatre of a formidable conflict between the detailed analysis of the Nazis criminal policy on the one hand, and his quest for identity which will doggedly affirm that he belongs to German culture. For a long time, the journal will confirm Klemperer's choice to stay in Germany in spite of the Nazis, even if staying eventually becomes synonymous with the inability to remain detached from what is happening around him. Thus, in spite of his criticism, Klemperer will be all but incapable of escaping the machinery of genocidal logic, a fact having great significance for the media exposure given to genocide in our time.

The excerpts we have chosen will serve to illustrate the tragedy of conscious thought caught in its own trap. The following passage represents the culmination of an inner struggle which grows out of the narrative project to go all the way and its logical consequence, the enactment of extreme events, giving rise to the following question: to what extent can the act of writing create favorable conditions for the commission of a criminal act? It is the eve of the destruction of Dresden which took place on the night of February 13, 1945, in which the deaths numbered in the tens of thousands.

4 In our research on genocide narratives, we treated this social semiosis as an act of designation by means of which the S. S. speaker defines the category to which his victims belong (Rinn 1999b). 
$13^{\text {th }}$ February [1945], Tuesday afternoon, perfect spring weather

(I) Odysseus in Polyphemus's cave. - Yesterday afternoon Neumark had me called over; I had to help him deliver letters this morning. I was quite unsuspecting. In the evening Berger was up here with me for a while, I told him, and he was annoyed and said, it'll be for digging trenches. I still did not grasp the seriousness of the threat. [...]

(II) For the first quarter of an hour my heart let me down completely, then later I was completely blunted, i.e. I made observations for my diary. The circular to be delivered stated that one had to present oneself at 3 Zeughausstrasse early on Friday morning, wearing working clothes and with hand luggage, which would have to be carried for a considerable distance, and with provisions for two to three day's travel. On this occasion there is to be no confiscation of property, furniture etc., the whole thing is explicitly no more than outside work duty - but is without exception regarded as a death march. The most cruel separations are taking place: Frau Eisenmann and Schorschi stay here, Lisel, the 11-year-old [girl] who wears the star, has to leave with father and Herbert. No allowance is made for old age or youth, not for 70 nor for 7 - what they mean by 'capable work' is quite incomprehensible. [...]

(III) Even more pitiful was Frau Bitterwolf in Struvestrasse. Again a shabby house; I was vainly studying the list of names in the entrance hall when a blonde, snub-nosed young woman with a pretty, well-looked-after little girl, perhaps four years old, appeared. Did a Frau Bitterwolf live here? She was Frau Bitterwolf. I had to give her an unpleasant message. She read the letter, she said several times, quite helplessly: 'What is to become of the child?', then signed silently with a pencil. Meanwhile the child pressed up against me, held out her teddy bear and, radiantly, cheerfully, declared: 'My teddy, my teddy, look!' The woman then went silently up the stairs with the child. Immediately afterwards I heard her weeping loudly. [...]

(IV) At Neumark's the whole office was crowded with those to be deported, I shook hands with Paul Lang, Reger, Lewinsky - 'You're coming too? No?' with that there was already a gulf between us. I went upstairs to the Eisenmanns for a moment, the whole family had assembled - extremely upset. I went to Waldmann, who remains here. He set forth the gloomiest hypothesis with very great certainty. [...] And we who remain behind, 'we have nothing more than a reprieve of perhaps a week. Then we'll be fetched out of our beds at six o'clock in the morning. And we'll end up just like the others.' I threw in: Why are they leaving such a small remnant here? And now, when they've got so little time? He: 'You'll see, I'll turn out to be right'. (Klemperer 2000: 493-495)

The passage recounts the last episode in the extermination of the Jews in Dresden. In February 1945, only a few dozen people remained from a community which included, according to the defining criteria established by the racial laws of Nuremberg, 4675 Jewish inhabitants in 1933. During the twelve previous years, from one deportation to the 
next, section by section, and at an unforeseeable yet inexorable pace, this population was methodically decimated. Klemperer, both lucid observer of this process and its designated victim, had every reason to fear the worst. In previously recorded notes, he had long acknowledged, in his own handwriting, the meaning of the kind of Arbeitseinsatz to which the Jews would be called.

Thus, the first paragraph raises the question as to why Klemperer refuses to acknowledge that at this precise moment he is playing the role of messenger of death. According to our hypothesis, his very method of investigation, his approval of his own reasoning is what makes him blind. Unlike the episode in which Ulysses visits Polyphemus, the famous passage in The Odyssey to which he refers, here the weapon used in an attempt to deceive the Nazi Cyclops backfires on him. The act of writing, instead of enabling him to remain impartial in his evaluation of the Nazis' murderous logic, helps to seal his own fate and that which is reserved for the Jewish community.

In the second paragraph, an unbearable passage, the juxtaposition between apathy and testimony dramatizes the reversal of the ancient scenario. If Ulysses introduces himself to his jailer as "Nobody", a ruse that facilitates his survival and that of his companions, Klemperer is precisely forced to adopt the identity of "Nobody", a non-subject reduced to a state of radical passiveness and entirely abandoned to the mechanism of destruction, a role that enables him to return to the observation post, an indispensable condition for the writing of his Diaries. The next sequence shows Klemperer as he is drawn into the depths. In his role as messenger of death, but already incarnating "Nobody", he meets actual human beings, Frau Eisenmann, Schorschi, Lisl, Herbert, and Frau Stühler who, once they have signed the circular, will in turn be plunged into the anonymity of the human masses destined for extermination.

The most shocking scene is that of the little girl who, already deprived of her name, asks Klemperer to look at her teddy bear (III). But Klemperer can no longer answer her; in the eyes of "Nobody", this little girl is already doomed to death. Indeed, the written trace left by the messenger of death testifies to the unbearable violence used by the Nazi regime in its attempt to destroy a human community. But how can one reconcile redemptive writing with the fact of being the spokesman for Evil? 
When Klemperer's task has been completed and he returns to the Jewish community office (IV), he becomes aware of the process that is taking place, the separation between those destined to be put to death in the near future, and those whose sentence has been deferred. But what escapes him and his unfortunate interlocutors is that their attempt to understand what is happening to them will always come up against the narrow limits imposed by Nazi logic. So long as the latter prevails, any kind of reasoning that tries to go beyond this incommensurable, radical Evil will be doomed to failure. Nonetheless, the remarkable quality of the Diaries consists in rigorously exploring this zone of impossible truth, ever trying to remain disengaged from the ultimate limit, up to the moment when the act of writing itself becomes instrumental in the production of nothingness.

The first part of the Diaries nonetheless shows that the mental gap between Nazi logic and the meaning Klemperer tries to assign it in everyday life defines his very writing project. Thus, the passage dated February 21, 1933, afternoon:

(I) Increasingly I fall back on reading aloud. Own work almost completely at a standstill. A review for the Germ.-Rom. Literaturblatt, that's all. I've put aside the 'Image of France' once again. Perhaps during the holidays. On the one hand I'm tortured by a lack of time: a drudge lighting stoves, washing up, shopping; on the other a sense of worthlessness. What difference does it make if I leave behind more or less one book! Vanitas...

(II) Lectures are coming to an end. Today is my last Tuesday because it's Carnival next week. For some while I've been reading the Italy course to four, five people. Monday the conclusion of the France course - next semester the lecture theatre will be even more gapingly empty. Things are throttled more and more.

(III) For something like three weeks now the depression of the reactionary government. I am not writing a history of the times here. But I shall nevertheless record my embitterment, greater than I would have imagined I was still capable of feeling. (Klemperer 1999b: 4)

Klemperer draws up a list of the elements that have created a strong feeling of gloom in him: his research is no longer progressing, housework is becoming a burden, and the number of students following his courses keeps shrinking. Rather than constituting the psychological self-portrait of a fatalist, this assessment gives particular meaning to the era in which he lived. Hitler has just been appointed chancellor on January 30, 1933 - and he has not yet been granted full powers. 
Klemperer is thus not yet a victim of the measures against Jews that he will subsequently relate in all their monstrosity. Nonetheless, his branch of teaching no longer suits the spirit of the times, for a new mentality had taken hold well before Hitler's takeover. Thus, considering the German original (I'm suffocating), one must interpret reference to the garrote as the manifestation of a Kulturkampf launched by the National-Socialist movement.

Therefore, the resentment felt by Klemperer does not stem from the fact that he feels personally threatened by the course of History, but from an ever greater questioning of German culture as he sees it. The journal thus becomes a weapon that he will use to prove over and over that he belongs to that culture. He will emerge as the victor in this inner struggle as long as he is able to explore the field of observation assigned to him. But, as we noted in the previous passage, once he is removed from his observation post, this weapon will backfire on him, leaving him at the mercy of Nazis' Weltbild.

Most of the journal occupies an intermediate position, however. In spite of the continual aggravation of his situation, Klemperer manages to view himself and his entourage with lucidity, which enables him to preserve a degree of independence - albeit relative - with respect to the ongoing extermination process. The description of his incarceration in the prison at the Dresden police station from June 23 to July 1, 1941 exemplifies this tendency. Entitled "Cell 89", the note begins with a recollection of the events that led to his conviction: an unboarded window at night, the reporting of this all in all minor incident, punishable by a mere warning and, finally, the sentencing to one week's imprisonment on account of the " $\mathrm{J}$ " on his identity card.

The sequences we have chosen form a part of the narrative that begins when Klemperer crosses the prison threshold:

Cell $89,23^{\text {rd }}$ June $-1^{\text {st }}$ July 1941

(I) For a moment I thought: 'Cinema'. A huge rectangular hall; glass roof, six galleries with glass floors, as if to break the fall of trapeze artists, but behind all the bright transparency the uniform rows of dark spots, the handleless cell doors. [...]

(II) 'Undo your tie, unbutton your braces. Faster. In the time it takes you to remove your tie, I'd be completely undressed.' It did not sound excessively brutal, but the order was roughly given. Only now did I know I was not watching a film. 'How shall I hold up my trousers?' - 'With your hands. You can pull them tight somehow in your cell. Your briefcase. Nightshirt and 
toothbrush you can keep, hairbrush is superfluous, books and spectacles stay here.' — 'But I was told...' — 'We make the rules here.' [...]

(III) How could I know beforehand, what imprisonment, what a cell is? Only at the second that the door fell shut, that the latch fell into place, did I know it with a nameless fear. [...]

(IV) I came out of the shock of the door shutting because of a loud, regular, continuous hammering sound above my head, tap-tap-tap-tap. I realized immediately: the prisoner above me is pacing his cell. [...] I had to break free of this idea of emptiness. The cell was my room, equipped with all that was necessary, I had only to study it in every detail. [...]

(V) War reports no doubt, the usual victories, the usual ridicule and abuse of enemies - of what interest was it to me in my cage? The excitement with which I normally waited for these reports was extinguished just as was the need to smoke. But now I clearly heard unintelligible, 'Deutschland über alles' and the Horst Wessel Song. So a big routine, a special announcement, some very big success. Only now did I think of the Russian campaign, which I had used to raise my spirits on the last Sunday at home - how dreadfully long ago that was. And all at once I was afraid the final victory could be Hitler's and with it his permanent rule. (Klemperer 1999b: 477-499)

In the first three passages (I-III), we can recognize a typical characteristic of the Diaries: describing the dispossession of his ability to comprehend the reality with which he is confronted, Klemperer tries to reconstitute the cognitive processes used to familiarize himself with the new situation. If he is still able to list the objects before his eyes, the staging of this situation escapes him and forces him to live in an unspeakable present. Deprived of the spectator's role that he has been compelled to adopt in order to preserve a certain form of existence, he becomes aware of the abyss opening before him.

The next sequence (IV) shows how Klemperer tries to restore meaning to this present. Placed in a position of radical inferiority with respect to the masters of the house, he begins to reconstruct a tangible reality, reassembling the known, identifiable, nameable elements. In the isolation of cell 89 , Klemperer thus sets about reclaiming this limited zone. This act of sheer willpower fills several pages in the Diaries, revealing remarkable psychological and intellectual strength. But according to the theory that we have tried to explore in this essay, the density of this mental work is precisely what makes him forget that imprisonment is an integral part of the dehumanization process of which he is a victim. Paradoxically, by asserting himself he appears simultaneously to dispossess himself. 
In the last paragraph (V), the intrusion of the outside world, crudely proclaiming the victory of the Hitlerians, brings Klemperer cruelly back to the reality surrounding him. Existential fear unmasks his mode of existence through a writing project conceived of as a philological construct that will have no influence on the course of events.

\section{A semiotics of annihilation}

Our second hypothesis, using pathos as a means for structuring argumentation, attempts to show how the presence of testimony responds to the absence of body. Writing thus helps to accredit the loss of his own corporality. The somatic invests the cognitive, carnal life touches social life, the denotatum invests the sign, the thing says the word. Victor Klemperer's Diaries show that in an extreme situation the rhetorical act can no longer deal with the domain of the plausible, but with that of truth - the destruction of one's own body, a process which seems implausible. Indeed, the state of non-subject will always remain beyond the reach of cognition.

As the following excerpts illustrate, words progressively lose their power of representation. From now on, the receptor must try to understand them literally. This reversal of the structure of meaning consists in systematically leveling the semantic categories that rule the conventional world of meaning.

$10^{\text {th }}$ August [1933], Thursday

A friend freed from a concentration camp. There, as a man who wears spectacles, he had to answer to the name "spectacle hound", he had to fetch his food bowl crawling on all fours if he wanted to eat any food. (Klemperer 1999b: 34)

In this passage, Klemperer relates the experience of a political prisoner imprisoned for an insignificant reason. The semantic transfer from the category of human animate concrete to that of animal animate concrete appears, however, to be a key element in the Nazis' strategy of progressively marginalizing a part of the German population as soon as they took power. If Klemperer complains of being more and more isolated during this same year, 1933, another way of expressing the first signs of the deterioration of his social situation, he uses a powerful metonymy to characterize the "leper" 
status to which the openly racist Nazi policy has reduced him in 1938 . This transfer of meaning from the human animate concrete to the natural inanimate concrete already foreshadows the measures that will progressively lead to the physical annihilation of the Jewish people.

\section{$13^{\text {th }}$ January [1940], Saturday evening}

The situation is made infinitely more difficult by the unsuspecting tomcat, whom we keep alive with almost the whole of our meat ration and for whom our moving out will be a death sentence. Eva is passionately fond of the poor creature, which is basically better off than we are. (Klemperer 1999b: 397)

Unlike the previous passage, this one shows a correspondence between the human and animal conditions in Klemperer's life. The domestic animal, recalling his former life, can be kept alive only at the expense of his master, on account of the food shortage among the Jewish population. In this passage we see how the procedures of meaning through concretion are intertwined with those that function by abstraction. As of 1940, Klemperer will experience ever greater difficulty in keeping himself at a distance from the policy of annihilation to which he is subjected as a designated non-subject. Thus we read:

$30^{\text {th }}$ August [1940], Saturday

I am now wearing the unfashionably tight trousers of a suit from about 1922, my carpet slippers are nearing their end, the situation with socks is very bad [...] [It] is impossible to see how I can continue to get by with respect to clothing. But we have strictly accustomed ourselves not to think beyond tomorrow. (Klemperer 1999b: 431)

The last clause shows how the body's foregrounding, responding to the imperative of physical survival, limits the procedures of cognition. In spite of impressive willpower, Klemperer will find it very difficult to venture beyond the spatio-temporal field dictated by the mere present. One might think that the reduction of intellectual faculties was an integral part of the Nazis' criminal strategy. Thus, one of the numerous official decrees which Klemperer mentioned in his Diaries: "It is to be emphasized that Jews are not allowed to store foodstuffs, but only to buy as they need for immediate consumption" (March 27, 1942; Klemperer 2000: 41). Accordingly, our second hypothesis holds that argumentation by means of pathos contributes to a kind of 
knowledge that can be qualified only as somatic, bestowing complete meaning upon mere corporal presence.

$19^{\text {th }}$ June [1942], Friday forenoon

Until now I had found our situation just as literally unimaginable: I had always been told about being beaten and spat upon, of trembling at the sound of a car, at every ring at the door, of disappearing and not coming back again - I had not known it. Now I know it, now the dread is always inside me [...]. (Klemperer 2000: 100)

Using somatic knowledge, Klemperer is able to give meaning to linguistic concretion. As shown by the entry on July 2, 1942, he can now have recourse to a pathemic topology in appropriating his state of non-subject: "Hunger, which in the last few days has ceased to be in any way metaphorical" (Klemperer 2000: 110). The leveling of semantic categories, blocking conventional transfers of meaning between the known and the unknown, thus creates what Klemperer (note of July 5, 1942; Klemperer 2000: 114) calls "the thought of extinction". Paradoxically, this essentially somatic form of thought appears to lack a cognitive dimension: "we know nothing of the present, because we were there" (note of July 2, 1942; Klemperer 2000: 115). But the destruction of established semantic hierarchies makes it possible for him to define the place of annihilation - his body - as a place held in common, a shared place of habitation for the bodies doomed to annihilation. Viewed as a discursive topos, the place where all bodies intermingle is constitutive of meaning 5 .

The following passage which relates the final destruction of Dresden exemplifies this:

Piskowitz, $22^{\text {nd }}-24^{\text {th }}$ February [1945]

Fires were still burning in many of the buildings on the road above. At times, small and no more than a bundle of clothes, the dead were scattered across our path. The skull of one had been torn away, the top of the head was a dark red bowl. Once an arm lay there with a pale, quite fine hand, like a model made of wax such as one sees in barber's shop windows. Metal frames of destroyed vehicles, burnt-out sheds. Further from the centre some people had been able to save a few things, they pushed handcarts with bedding and the like or sat on boxes and bundles. Crowds streamed unceasingly between these islands, past the corpses and smashed vehicles, up and down the Elbe, a silent, agitated

5 As Jacques Rancière has shown in Malaise dans l'esthétique (2004: 145-173), the concept of "indistinction" has an important political issue. 
procession. Then we turned right towards the town again - I let Eva lead the way and do not know where. (Klemperer 2000: 500-501)

In the description of this confusion, one can note how the indistinction of semantic categories is precisely what enables the author to juxtapose animate and inanimate bodies indiscriminately. We can recognize here the fusional principle of Klemperer's pathemic argumentation. Confronted with an impossible choice on account of the inextricable mixture of bodies, he decides to blend in with the crowd of wandering bodies that invade Germany this spring of 1945.

\section{Conclusion}

As we have seen, in spite of his remarkable background in the humanities, his mastery of philological methods and an unfailing analytical sense with respect to his own person, Victor Klemperer was unable to escape the Nazi doxa which he criticized so tenaciously. Those among us who see themselves as the distant successors of this Romance philologist will thus have every reason to fear the worst: the failure of their critical enterprise before the growing power of increasingly totalitarian information networks whose forerunner was the model put in place by the Nazi regime. To establish the meaning of the place of extermination is thus to carry out an ultimate act of resistance.

Reading the Diaries will also contribute, however, to the discovery of a more secret conversion, that of a human being reduced to the state of non-subject, of "Nobody", refusing to silence himself and to silence voices who have forever disappeared in the turmoil. Victor Klemperer - precisely by naming his body - will thus have infinitely surpassed the limit set by the Nazis. The validation of somatic knowledge makes it possible to break the link between monstration and signification, opening up the possibility of choices to the speaking subject. Thus, the mixing of the argumentative domains of ethos and pathos that characterizes Victor Klemperer's journal allows us to analyze the functioning of an action language whose esthetico-ethical importance in contemporary discourse merits further study. ${ }^{6}$

6 Translated by Thomas Buckley, Université de Bretagne Occidentale. 


\section{References}

Amossy, Ruth (ed.) 1999. Images de soi dans le discours. La construction de l'ethos. Lausanne-Paris: Delachaux et Niestlé.

Dirschauer, Johannes 1997. Tagebuch gegen den Untergang: zur Faszination Victor Klemperers. Giessen: Psychosozial-Verlag.

Jacobs, Peter 2000. Victor Klemperer - im Kern ein deutsches Gewächs: eine Biographie. Berlin: Aufbau-Verlag.

Kertész, Imre 1999. Le vingtième siècle est une machine à liquider permanente. In: Coquio, Catherine (ed.), Parler des camps, penser les génocides, Paris: Albin Michel, 87-92.

Klemperer, Victor 1989. Curriculum vitae. Erinnerungen eines Philologen 18811918. Berlin: Siedler Verlag.

- 1996. Leben sammeln, nicht fragen wozu und warum. Tagebücher 1918-1932. Berlin: Aufbau-Verlag.

- 1999a. So sitze ich denn zwischen allen Stühlen. Tagebücher 1945-1959. Berlin: Aufbau-Verlag.

- 1999b. I Shall Bear Witness. The Diaries of Victor Klemperer 1933-1941. (Chalmers, Martin, trans.) London: Phoenix.

- 2000. To the Bitter End. The Diaries of Victor Klemperer 1942-1945. (Chalmers, Martin, trans.) London: Phoenix.

Levi, Primo 1989. Les naufragés et les rescapés. Paris: Gallimard.

Mieder, Wolfgang 2000. "In lingua veritas": sprichwörtliche Rhetorik in Victor Klemperers Tagebüchern 1933-1945. Wien: Edition Praesens.

Rancière, Jacques 2004. Malaise dans l'esthétique. Paris: Galilée.

Rinn, Michael 1998. Les récits du génocide. Sémiotique de l'indicible. LausanneParis: Delachaux et Niestlé.

- 1999a. Poétique de la Shoah. Non lieux et lieux communs. La Licorne 51: 2743.

- 1999b. L'Holocauste dans les récits d'enfants. Pour une sémiotique des points de vue. In: Gautier, Robert (ed.), Violence et Langage. Toulouse: Presses Universitaires du Sud, 113-132.

- 2000. Pour une sémantique des récits de la Shoah. Approches de la doxa millénariste. In: Rambaldi, Enrico Isacco (ed.), Millenarismi nella cultura contemporanea. Milano: Franco Angeli, 133-156.

- 2005. Imre Kertész: une écriture de l'extrême contemporain. In: Dornier, Carole; Dulong, Renaud (eds.), Esthétique du témoignage. Paris: Editions de la maison des sciences humaines, 61-69. 


\section{Называние тела никого: правда в дневниках Виктора Клемперера}

Немецкий филолог и профессор Дрезденского университета Виктор Клемперер описывает в своих дневниках свое выживание в период нацизма (1933-1945). Клемперера из-за его приверженности иудаизму последовательно выдворяли из общественной жизни, пока наконец, к концу войны ему не пришлось признать себя «не-субъектом», называя себя по примеру Одиссея «Никто». Цель моей статьи - показать ментальный (когнитивный и телесный) процесс этого узнавания. Анализируется двунаправленность этого процесса: оказавшись лицом к лицу со своим неизбежным уничтожением, Клемперер был вынужден признать ограниченность своих аналитических способностей. Но этот пограничный опыт позволяет ему дойти до соматического понимания идеи «вымирания». Настоящий текст демонстрирует рождение этой логики из языкового употребления, сосредоточенного на назывании тела.

\section{Eikellegi keha nimetamine: Tõde Victor Klempereri päevikutes}

Saksa filoloog ja Dresdeni Ülikooli professor Victor Klemperer kirjeldab oma ellujäämist natsismiperioodil oma päevikutes (1933-1945). Klempereri sunniti juudi usu tõttu järk-järgult taanduma kogu seltsielust, kuni viimaks, sõja lõpus tuli tal end tunnistada mitte-subjektiks, nimetades end Odüsseuse ja kükloop Polyphemuse loo eeskujul "Eikeegiks". Minu artikli eesmärgiks on näidata selle äratundmise mentaalset — kognitiivset ja kehalist - protsessi. Minu analüüs jälgib selle protsessi kaheharulisust: seistes vastamisi enda vältimatu hävinguga, tuleb Klempereril tunnistada oma analüütiliste võimete piiratust. Kuid see äärmuslik kogemus lubab tal jõuda "väljasuremisidee" somaatilise mõistmiseni. Käesolev tekst demonstreerib seda, kuidas see loogika sündis keha nimetamisele keskenduvast verbilisest keelekasutusest. 
